УДК 330.3;338.4:004.773

DOI: https://doi.org/10.37320/2415-3583/9.6

Робул Ю.В.

кандидат фізико-математичних наук, доцент, доцент кафедри маркетингу та бізнес-адміністрування, Одеський національний університет імені I.I. Мечникова ORCID: https://orcid.org/0000-0002-7299-9648

\title{
ДИНАМІКА РОЗВИТКУ МАРКЕТИНГОВИХ СИСТЕМ, РОЗВИТОК ІННОВАЦІЙ І ЗАВДАННЯ МАРКЕТИНГОВОЇ ПОЛІТИКИ
}

Статтю присвячено аналізу изілей маркетингової політики комериійної організації залежно від стану маркетингової системи, зумовленого виробництвом та впровадженням і подальшим розвитком інновацій. Функція иілепокладання в маркетингу є сполучною ланкою, яка з'єднує, з одного боку, макрорівень, представлений маркетинговою системою вищого ступеня охоплення, а з іншого - мікрорівень, маркетинг-менеджмент на рівні окремої фірми. Разом із тим правильне цілепокладання забезпечує зв'язок між виробництвом інновацій, маркетинговою політикою та результативністю торгівлі. 3 використанням концепту ринку як мережевої взаємодї, маркетингової системи як середовища реалізації маркетингової політики та багаторівневого продукту запропоновано систематизацію иілеи маркетингу залежно від динамічного становища маркетингової системи, зумовленого співвідношенням попиту і пропозиції та рівнем інновачіi.

Ключові слова: маркетинг, інноваиї̈, продукт, маркетингова система, маркетинг-менеджмент, изілі маркетингу.

Постановка проблеми. Маркетинг $є$ неодмінним інструментом підприємництва та управління організацією в умовах ринкової економіки, головне призначення якого полягає у налагодженні та підтримці ринкових обмінів шляхом створення та доставки споживчої цінності на основі визначення та передбачення потреб і бажань цільових споживачів, інших зацікавлених сторін та широкої громадськості з метою отримання вигоди. В умовах конкуренції покупець опиняється перед проблемою вибору. Завдання маркетингу полягає у тому, щоб вплинути на вибір покупця у напрямі, сприятливому для даної організації. Рішення окремого покупця і розгортання маркетингової політики організації відбувається у соціумі. Маркетингова політика, iï цілі та вибір інструментів реалізації перебувають під впливом сил, які визначають стан і динаміку економічного та соціального розвитку. Відповідно, маркетинг є економічним, управлінським і соціальним процесом одночасно, який пов’язує організацію, ії цільові групи покупців, партнерів, інших зацікавлених осіб та широку публіку покупців через обмін цінностями, які становлять для них інтерес.

У розумінні маркетингу, а надто у практиці його використання на рівні окремої організації до цього часу панує концепція маркетинг-менеджменту, започаткована у США наприкінці 50-х початку 60 -х років XX ст. Маркетинг розглядається як одна 3 функцій організації, реалізована за допомогою специфічної конфігурації стандартних інструментів, знаних під назвою комплексу маркетингу (marketing mix), запроваджених у науковий обіг ще на початку 1960 -х років. Від того часу маркетингова реальність значно змінилася, що все ще не знаходить адекватного відображення у цілях, стратегіях та базових інструментах реалізації маркетингової політики на рівні організації, так само як і у навчальних програмах 3 маркетингу. На цьому рівні він залишається достатньо одноманітним, пропонуючи типове вирішення завдань, які постають перед організацією у царині взаємодія «фірма - ринок», звертаючи мало уваги, 3-поміж іншого, на те, що ці взаємовідносини можуть мати різну природу, характеризуватися різним розподілом та поширенням влади і впливу, залучати до обміну різну кількість учасників із різними формами зв'язку між ними.

Аналіз останніх досліджень i публікацій. Критика традиційного маркетинг-менеджменту як надто обмеженої та негнучкої функціональної стратегії організації не $є$ новою. У відомому огляді концепцій маркетинг-менеджменту Ф. Уебстер [1] ратує за вироблення «нової парадигми маркетингу всередині фірм». Е. Гуммессон [2] зазначає, що концепція маркетинг-менеджменту розглядає маркетинг виключно як функцію організації і не бере до уваги різницю у характері взаємодії фірм та споживачів. К. Грьонросс у цьому зв'язку зазначає, що «сучасний маркетинг є процесом взаємодії у соціальному контексті, основою якого є розбудова мережі партнерських стосунків» [3], а ініціатива в обмінах належить не тільки фірмі, і тим більше не лише ії маркетинговим підрозділам. Прогрес у розвитку технологій, передусім інформаційно-комунікаційних, призвів до того, що всі ринки, у тому числі й споживчі ринки товарів масового попиту, характерні особливості яких концепція маркетинг-менеджменту враховує найповніше, зазнали принципових змін, пов'язаних із появою можливостей для споживачів зайняти активну позицію у взаємодії з фір- 
мами та між собою. У цифровому середовищі споживачі більше не є тільки тими, для кого створюється продукт, вони стають співтворцями цінності [4] та активними провідниками інформації, а не лише її отримувачами, тоді як лояльні споживачі, по суті, перетворюються на партнерів, які забезпечують обізнаність та підтримку (advocacy) власним досвідом та мережею особистих зв'язків. Холістична концепція [5; 6] робить спробу врахувати розширення предметної сфери маркетингу у маркетинг взаємовідносин, соціальну відповідальність бізнесу та внутрішні процеси функціонування фірми, проте, як і раніше, залишає відкритим питання про цілі маркетингової політики. Якими вони мають бути? Чи є вони однаковими для всіх типів ситуацій, у яких може опинитися фірма, для всіх типів зовнішнього середовища? Дана стаття досліджує питання форми та змісту цілей маркетингової політики організації як функції становища маркетингового середовища, у якому здійснюється маркетинг.

Мета статті полягає у визначенні основних станів маркетингового середовища, які безпосередньо впливають на характер та зміст маркетингової політики організації, та систематизації цілей і завдань маркетингу відповідно до конкретного становища.

Виклад основного матеріалу. Маркетингова політика кожної організації не здійснюється ні ізольовано від інших, ні у вакуумі. На неї безпосередньо впливають партнери, постачальники, конкуренти та групи впливу, бізнес-моделі, притаманні конкретній галузі, а опосередковано - чинники маркетингового макросередовища: політико-правові, економічні, соціокультурні, технологічні, екологічні та демографічні. Кожен конкретний акт взаємодії між продавцем і покупцем є результатом складної сукупності чинників та обставин, що розвиваються у часі. Значна частина цих чинників є взаємозалежними, а велика кількість умов робить попит і пропозицію на ринку в цілому неоднорідною. Обмін цінностями означає, що продавець та покупець пов'язуються специфічними взаємовідносинами залежності різної тривалості та складності, у яких обидві сторони можуть грати активну роль $[3 ; 7 ; 8]$ Взаємодія являє собою результат попередніх пов'язаних між собою взаємодій різних учасників ринку, який, своєю чергою, породжує множину наслідків для інших взаємопов'язаних учасників. Таким чином, ринок може бути описаний як мережева взаємодія, яка реалізується за допомогою процесів множинної пов'язаної взаємодії багатьох учасників із використанням специфічних інститутів. Таку сукупність дотичних до ринку об'єктів, процесів та інститутів називають маркетинговою системою [9; 10]. Маркетингова система є середовищем реалізації маркетингової політики. Вона характеризується такими властивостями [11]:

1. Маркетингові системи виходять за рамки простого економічного обміну, оскільки в контексті обміну існують соціальні, поведінкові, моральні, юридичні та психологічні чинники, крім економічних.

2. Маркетингові системи безпосередньо пов'язані з іншими системами соціуму.

3. Маркетингові системи містять інші підсистеми, тому необхідно враховувати рівні складності кожної 3 них для визначення розмірів та ефективності.

4. Кожна маркетингова система має специфічні

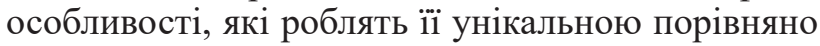
3 іншими системами.

5. Кожна система має певний рівень і межу ефективності, яка визначається з урахуванням усіх внутрішніх і зовнішніх елементів та обставин.

6. Маркетингова система є динамічним утворенням та еволюціонує в часі.

Початок функціонування кожної нової маркетингової системи логічно вбачається у створенні нового товару.

Розвиткові маркетингової системи у позитивному напрямі притаманне зростання ентропії [12], яке, серед іншого, втілюється у зростаюче розмаїття асортименту пропозицій цінності [13].

Становище маркетингової системи визначається такими чинниками, як мотивація учасників ринкових обмінів та всіх дотичних до них сторін, наявність посередників та зміст їхніх послуг, соціальні умови тощо, але в першу чергу - співвідношення попиту і пропозиції. Результат функціонування маркетингової системи виявляється в економічному зростанні та урізноманітненні пропозицій цінності, яке є складовою частиною якості життя. Внесок маркетингової системи в економічний розвиток здійснюється через розподіл праці та пов'язану з ним реалізацію інновацій [13]. Динамічну модель функціонування маркетингової системи наведено на рис. 1.

Ця модель функціонування маркетингової системи дає підстави розглядати, з одного боку, співвідношення попиту і пропозиції, а з іншого якість та зміст інновацій, породжену експериментами підприємців і розподілом праці як чинників, які визначають динаміку маркетингової системи та впливають на зміст цілей та характер реалізації маркетингової політики [14].

У межах концепції ціннісних дисциплін визначення стратегії створення споживчої цінності, а через них - маркетингові цілі організації перебувають під визначальним впливом ключових компетенцій, які є передумовою або неодмінним складником створення цінності [15]. Особливе значення ключових компетенцій, відповідно, полягає у пошуку відповіді не лише на питання 


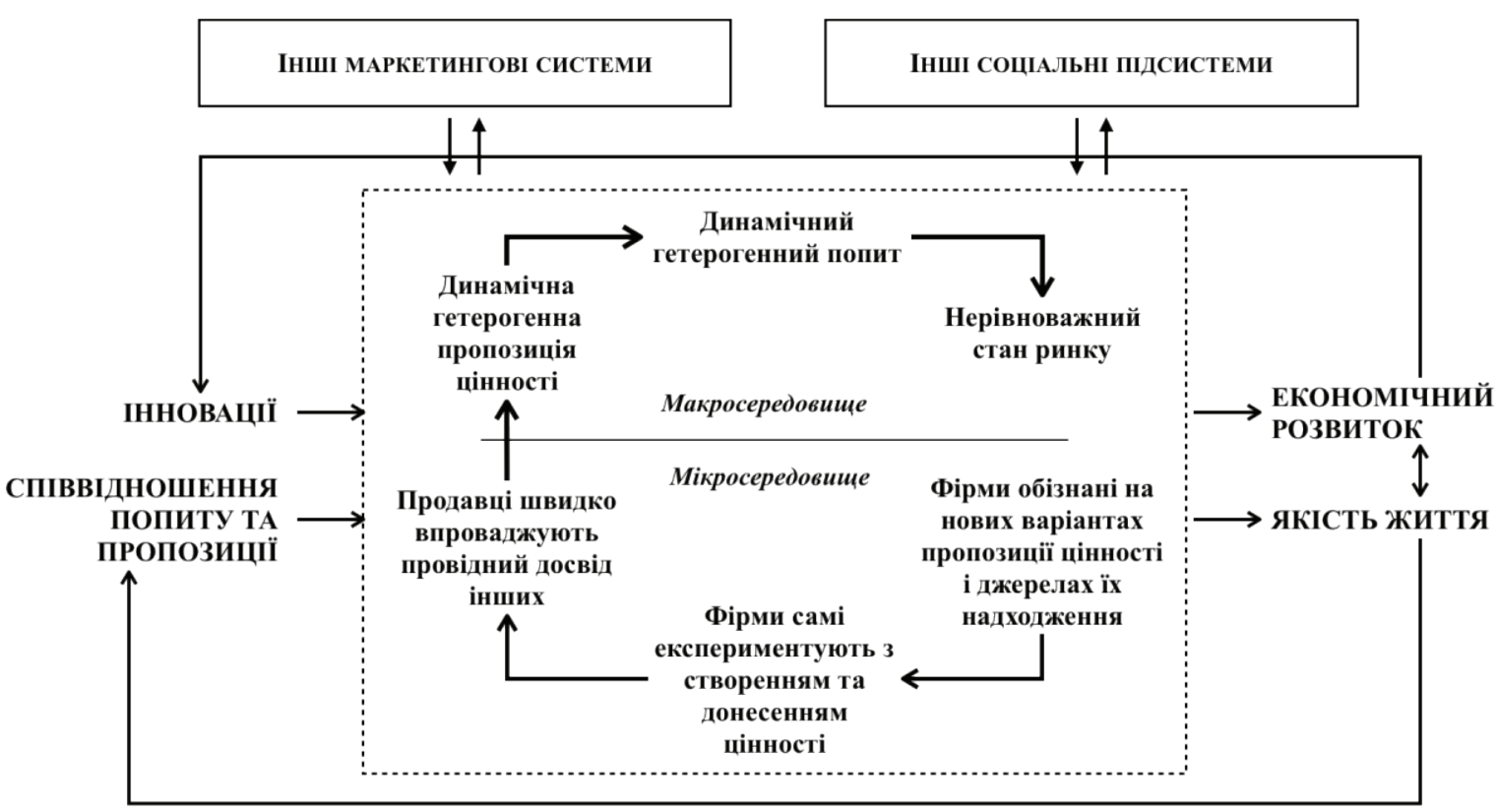

Рисунок 1 - Динамічна модель маркетингової системи

Джерело: власна розробка на основі [13]

«як створювати?», а й на питання «що створювати?» [16; 17]. Із практичного погляду інновації пропозиції цінності можна розділити відповідно до рівнів у концепції багаторівневого продукту [18]: інновації на рівні товару за задумом, інновації на рівні товару в реальному виконанні, та інновації на рівні розширеного продукту.

Інновацій на рівні товару у реальному виконанні означають появу нового товару «глобальної новизни» [14]. Цей результат може досягатися як проривною технологічною інновацією, так і систематизацією та видозміною ланцюга доданої вартості, як це відбувається під час створення «блакитного океану» [19]. У будь-якому разі такий розвиток подій позначає екстенсивний розвиток маркетингової системи, який спричиняється до виникнення тимчасової монополії, створеної довкола унікальної вигоди, створюваної інноваційним продуктом. Беручи до уваги обмежену в часі можливість одержувати монопольну вигоду, організація потребує якомога швидшого опанування ринку з метою забезпечення власних доходів та обмеження ринкових можливостей імітаторів у майбутньому. Метою маркетингу в такому разі є запуск кривої життєвого циклу продукту та максимальне зростання рівня продажу. Пропозиція цінності у цьому разі орієнтується на базовий інноваційний продукт та його властивості значно більшою мірою, ніж на кастомізацію. Поява перших послідовників та руйнування тимчасової монополії зсувають завдання створення конкурентних переваг на рівень товару в реальному виконанні. На цьому етапі конкуренти експерименmують у дусі Шумпетера $з$ новими конфігураці- ями та варіантами базової цінності і продовжують опановувати зростаючий ринок. Попит на даному етапі залишається розширюваним, і відбувається збільшення первинного попиту. Створення конкурентної переваги на цьому етапі залежить від здатності втілювати задум у життя 3 належним рівнем якості, передбачення та розуміння потреб споживачів, здатності творчо переосмислювати базову цінність товару. Як на першому, так і на другому етапі ринкова влада належить виробникові, хоча в міру появи конкурентів вона дедалі більше розмивається. За умов ринку продавця 3 конкурентами фінансовий результат фірми залежить від контрольованого обсягу ринку, а отже, головною метою маркетингової політики є збільшення частки ринку.

У міру появи конкурентів із часом пропозиція цінності урізноманітнюється, а ринковий потенціал здебільшого вичерпується. На ринках відбувається процес, до деякої міри подібний до природного відбору у живій природі. Підприємці експериментують із різними варіантами пропозиції цінності, а споживачі вибирають ті варіанти, які вважають найбільш цінними для себе. Менш успішні варіанти та конфігурації цінностей відкидаються споживачами і не пропонуються підприємцями, тоді як варіанти, що користуються попитом, дедалі більше копіюються. Цей процес призводить до стандартизації пропозиції цінності. Розмаїття асортименту, яке повинна продукувати маркетингова система, утворюється конкуруючими процесами експериментування 3 конфігураціями цінності з боку підприємців та відбором найбільш привабливих цінностей спо- 
живачами та їх тиражування фірмами. Урізноманітнення та диференціація стають можливими поза межами власне базового продукту шляхом обслуговування, створення та реалізації товарів-компліментів або розвитку нематеріальних активів. Конкурентна перевага залежить тепер не стільки від здатності винайти інновацію, скільки від уважності до висловлених потреб та бажань споживачів і здатності забезпечити належну сервісну підтримку. Основою для диференціації на цьому етапі $\epsilon$ наявність розвиненої спеціалізації у виробництві та споживанні, високий рівень добробуту та якості життя, який дає змогу здійснювати вибір функціонально схожих товарів, не поступаючись ціною як переважним критерієм. Достатньо розвинений ринок, високий рівень платоспроможного попиту та досвідчені споживачі $\epsilon$ ознаками екстенсивного розвитку до інтенсивного. В умовах недосконалої (монополістичної) конкуренції фірми змагаються за обсяг продажів, створюючи продукт із найкращими неціновими перевагами. У міру зростання спеціалізації та кастомізації відкриваються можливості непропорційного зростання прибутковості, що, своєю чергою, призводить до можливості інтенсивного зростання доходів, яке може бути досягнуто без збільшення частки ринку. Метою маркетингової політики в такому разі є збільшення ціни та відносне здорожчання продукції, поєднуване зі зростанням обсягу закупівлі та кількістю споживачів, якщо попит усе ще залишається розширюваним.

Подальший розвиток інновацій пов'язаний із розвитком нематеріальних активів. Використання цих активів для створення конкурентної переваги потребує довіри як найважливішого інституту маркетингової системи. У цьому разі головною метою маркетингової політики стає створення та підтримання репутації, створення і донесення репутації свого продукту як справжнього. Сучасні маркетингові системи розвиваються в бік розвитку автентичності [20], яка не може функціонувати без довіри.

Грунтуючись на сказаному вище, можна запропонувати систематизацію маркетингових цілей організації залежно від динамічного стану маркетингової системи, наведену в табл. 1.

Висновки. Урахування особливостей розвитку маркетингових систем обертається умноженням можливих цілей маркетингової політики, що має знаходити відображення у плануванні та розвиткові систем збалансованих показників у маркетингу. Неправильна постановка маркетингових цілей, які не відповідають рівню розвитку маркетингової системи, прирікає маркетинг на низьку результативність та ефективність, що ставить під питання доцільність використання маркетингу у діяльності підприємця у цілому. У запропонованому підході результативність маркетингу і його цілепокладання знаходяться у прямій залежності до здатності організації виробляти чи запозичувати інновації: експериментувати, конфігурувати цінність та швидко постачати iї на ринок. Важливо у цьому зв'язку відзначити не лише очевидну пряму залежність, коли маркетинг сприяє комерціалізації інновацій, а й менш очевидний зворотний зв'язок. Від рівня розвитку маркетингу загалом і від правильності постановки цілей маркетингу на рівні підприємства, зокрема, залежить характер вироблення інновацій, обсяг, зміст та значимість для економічного розвитку i добробуту.

Важливим є зв'язок підприємництва, інновацій та маркетингу. Маркетинг не просто сприяє задоволенню споживчих потреб і бажань, а й $є$ дієвим інструментом їх виявлення і забезпечує зв'язок інноваційного процесу та споживання:

Таблиця 1 - Цілі організації на різних рівнях розвитку маркетингової системи

\begin{tabular}{|c|c|c|c|}
\hline $\begin{array}{c}\text { Становище } \\
\text { маркетингової системи }\end{array}$ & $\begin{array}{l}\text { Екстенсивне } \\
\text { розширення }\end{array}$ & $\begin{array}{c}\text { Екстенсивне яке } \\
\text { переходить у інтенсивне }\end{array}$ & Інтенсивне розширення \\
\hline $\begin{array}{c}\text { Рівень створення } \\
\text { переваги відносно } \\
\text { маркетингового продукту }\end{array}$ & Товар за задумом & $\begin{array}{c}\text { Товар у реальному } \\
\text { виконанні }\end{array}$ & Розширений товар \\
\hline $\begin{array}{c}\text { Співвідношення попиту } \\
\text { та пропозиції } \\
\end{array}$ & Попит > Пропозиція & Попит $\approx$ Пропозиція & Попит < Пропозиція \\
\hline $\begin{array}{c}\text { Джерело створюваної } \\
\text { конкурентної переваги }\end{array}$ & $\begin{array}{c}\text { Функціональні } \\
\text { властивості продукту }\end{array}$ & $\begin{array}{c}\text { Якість, сервіс, } \\
\text { знання обізнаність на } \\
\text { споживачеві }\end{array}$ & $\begin{array}{c}\text { Позитивний досвід } \\
\text { споживачів, спільне } \\
\text { створення цінності } \\
\text { (co-creation) }\end{array}$ \\
\hline $\begin{array}{c}\text { Головна мета } \\
\text { маркетингової політики }\end{array}$ & $\begin{array}{c}\text { Збільшення обсягу } \\
\text { продажу, частка ринку }\end{array}$ & $\begin{array}{c}\text { 3більшення прибутковості } \\
\text { відносно конкурентів, } \\
\text { збільшення та утримання } \\
\text { частки ринку } \\
\end{array}$ & $\begin{array}{l}\text { Створення та збільшення } \\
\text { цінності нематеріальних } \\
\text { активів, репутація, довіра }\end{array}$ \\
\hline $\begin{array}{c}\text { Специфічне } \\
\text { джерело доходів }\end{array}$ & Обсяг продажу & Підвищена прибутковість & Лояльність \\
\hline
\end{tabular}

Джерело: власна розробка автора 
знаходить можливості для прибуткової реалізації інновації шляхом створення унікальної пропозиції цінності та живить інноваційний процес, постачаючи матеріальні ресурси від успішної реалізації раніше створених товарів і послуг, а також постачаючи відомості про запити споживачів, які можуть визначати зміст подальших інновацій. Окрім того, підтримуючи ринкові обміни, маркетинг долучається до формування позитивного образу та капіталу бренду фірми-виробника, що $є$ важливою умовою успішної комерціалізації наступних інновацій. Для реалізації цього процесу принципово важливими стають правильна постановка маркетингових цілей на рівні організацій та належне продуктивне функціонування маркетингових систем.

\section{Список використаних джерел:}

1. Webster F.E. The Changing Role of Marketing in the Corporation. Journal of Marketing. 1992. T. 56. № 4. P. 1-17.

2. Gummesson E., Lusch R.F., Vargo S.L. Transitioning from service management to service-dominant logic: Observations and recommendations. International Journal of Quality and Service Sciences. 2010. T. 2. № 1. P. 8-22.

3. Grönroos C. Quo Vadis, marketing? Toward a relationship marketing paradigm. Journal of Marketing Management. 1994. T. 10. № 5. P. 347-360.

4. Prahalad C.K., Ramaswamy V. Co-Creation Experiences: the Next Practice in Value Creation. Journal of Interactive Marketing. 2004. T. 18. № 3. P. 5-14.

5. Загорна Т.О., Стасюк О.М. Концепція холістичного маркетингу: джерела проблематики та елементи. Маркетинг і менеджмент інновачій. 2012. № 2. С. 32-38.

6. Робул Ю.В. Холістична концепція ефективності маркетингу. Маркетинг і менеджмент інновацій. 2011. № 4(2). C. $124-130$.

7. Gummesson E. Making Relationship Marketing Operational. International Journal of Service Industry Management. 1994. T. 5. № 5. P. 5-20.

8. Sheth J.N., Purvatiyar A. Relationship marketing in consumer markets: antecedents and consequences. Journal of the Academy of Marketing Science. 1995. T. 23. № 4. P. 255-271.

9. Mittelstaedt J.D., Kilbourne W., Mittelstaedt R.A. Macromarketing as agorology: Macromarketing theory and the study of the agora. Journal of Macromarketing. 2006. T. 26. № 2. P. 131-142.

10. Layton R.A. Marketing Systems - A Core Macromarketing Concepr. Journal of Macromarketing. 2007. T. 27. № 3. P. 227-242.

11. Medeiros F.G. d., Costa F.J. d. Uma proposta de visualização do sistema agregado de marketing turístico. Estudios Gerenciales. 2019. T. 35. № 152. P. 237-248.

12. Kadirov D. Macro-Systems Role of Marketing. Journal of Macromarketing. 2011. T. 31. № 4. P. 359-375.

13. Layton R.A. On Economic Growth, Marketing Systems, and the Quality of Life. Journal of Macromarketing. 2009. T. 29. № 4. P. 349-362.

14. Lambin J.-J., de Moerloose C. Marketing stratégique et opérationnel. La démarche marketing dans l'économie numérique. Pari s: Dunod, 2016. 608 p.

15. Treacy M., Wiersema F. The Discipline of Market Leaders: Choose Your Customers, Narrow Your Focus, Dominate Your Market. Reading, MA : Addison-Wesley Publishing, 2007. 224 p.

16. Hamel G., Prahalad C.K. Strategic intent. Harvard Business Review. 2005. T. 83. № 7. P. 148.

17. Prahalad C.K., Hamel G. The Core Competence of the Corporation. Harvard Business Review. 1990. T. 68 . № 3. P. $1-13$

18. Котлер Ф., Келлер К.Л. Маркетинг менеджмент / пер. с англ. ; 15-е изд. Санкт-Петербург : Питер, 2018.848 с.

19. Чан Кім В., Моборн Р. Перехід до блакитного океану. Поза конкуренцією / пер. $з$ англ. Харків : Книжковий клуб клуб сімейного дозвілля, 2018. 288 с.

20. Kadirov D., Varey R.J., Wooliscroft B. Authenticity: A Macromarketing Perspective. Journal of Macromarketing. 2014. T. 34. № 1. P. 73-79.

\section{References:}

1. Webster, F. E. (1992). The Changing Role of Marketing in the Corporation. Journal of Marketing, 56(4), 1-17.

2. Gummesson, E., Lusch, R. F., \& Vargo, S. L. (2010). Transitioning from service management to servicedominant logic: Observations and recommendations. International Journal of Quality and Service Sciences, 2(1), 8-22. doi:10.1108/17566691011026577

3. Grönroos, C. (1994). Quo Vadis, marketing? Toward a relationship marketing paradigm. Journal of Marketing Management, 10(5), 347-360. doi:10.1080/0267257X.1994.9964283

4. Prahalad, C. K., \& Hamel, G. (1990). The Core Competence of the Corporation. Harvard Business Review, 68(3), 1-13.

5. Zahorna, T. O., \& Stasiuk, O. M. (2012). Kontseptsiia kholistychnoho marketynhu: dzherela problematyky ta elementy. [Holistic marketing concept: sources of issues and elements]. Marketynh i menedzhment innovatsii (2), 32-38.

6. Robul, Yu. V. (2011). Kholistychna kontseptsiia efektyvnosti marketynhu. [Holystic concept of marketing performance]. Marketynh i menedzhment innovatsii (4(2)), 124-130.

7. Gummesson, E. (1994). Making Relationship Marketing Operational. International Journal of Service Industry Management, 5(5), 5-20. Retrieved from http://www.emeraldinsight.com/journals.htm?articleid=851563\&amp;show=abstract

8. Sheth, J. N., \& Purvatiyar, A. (1995). Relationship marketing in consumer markets: antecedents and consequences. Journal of the Academy of Marketing Science, 23(4), 255-271.

9. Mittelstaedt, J. D., Kilbourne, W., \& Mittelstaedt, R. A. (2006). Macromarketing as agorology: Macromarketing theory and the study of the agora. Journal of Macromarketing, 26(2), 131-142. doi:10.1177/0276146706290921 
10. Layton, R. A. (2007). Marketing Systems - A Core Macromarketing Concepr. Journal of Macromarketing, 27(3), 227-242.

11. Medeiros, F. G. d., \& Costa, F. J. d. (2019). Uma proposta de visualização do sistema agregado de marketing turístico. [A proposal to analyze tourism from a macromarketing perspective]. Estudios Gerenciales, 35(152), 237-248. doi:10.18046/j. estger.2019.152.3262

12. Kadirov, D. (2011). Macro-Systems Role of Marketing. Journal of Macromarketing, 31(4), 359-375. doi:10.2307/1252112

13. Layton, R. A. (2009). On Economic Growth, Marketing Systems, and the Quality of Life. Journal of Macromarketing, 29(4), 349-362. doi:10.1177/0276146709345108

14. Lambin, J.-J., \& de Moerloose, C. (2016). Marketing stratégique et opérationnel. La démarche marketing dans l'économie numérique. Paris: Dunod.

15. Treacy, M., \& Wiersema, F. (2007). The Discipline of Market Leaders: Choose Your Customers, Narrow Your Focus, Dominate Your Market. Reading, MA: Addison-Wesley Publishing.

16. Hamel, G., \& Prahalad, C. K. (2005). Strategic intent. Harvard Business Review, 83(7), 148.

17. Prahalad, C. K., \& Ramaswamy, V. (2004). Co-Creation Experiences: the Next Practice in Value Creation. Journal of Interactive Marketing, 18(3), 5-14.

18. Kotler, F., \& Keller, K. L. (2018). Marketynh menedzhment [Marketing management]. (15th-ed.). St-Petersburgh: Piter. (in Russian)

19. Chan Kim, V., \& Mauborgne, R. (2018). Perekhid do blakytnoho okeanu. Poza konkurentsiieiu [Blue Ocean Shift]. Kharkiv: Vydavnytstvo Knyzhkovyi klub Klub Simeinoho Dozvillia. (in Ukrainian)

20. Kadirov, D., Varey, R. J., \& Wooliscroft, B. (2014). Authenticity: A Macromarketing Perspective. Journal of Macromarketing, 34(1), 73-79. doi:https://doi.org/10.1177/0276146713505774

\author{
Robul Yuriy
}

Odesa I.I. Mechnikov National University

\title{
DYNAMICS OF MARKETING SYSTEM DEVELOPMENT, INNOVATIONS AND GOALS OF MARKETING
}

The article is devoted to the analysis of the objectives of the marketing policy of a commercial organisation, depending on the state of the marketing system as function of production, implementation and further development of innovations. Marketing goal setting is a link that connects, on the one hand, the macro-level, represented by the marketing system of higher level of aggregation, and on the other, the micro-level, marketing management at the individual level of a firm. At the same time, proper goal setting provides a link between production of innovation and marketing policy and goals. However, theoretical links between innovations and marketing has not yet been properly studied. At the same time marketing goal setting currently poses many confusions, sometimes leading to apparent disruption in marketing processes and policy disguised by wording about "death of marketing as we knew it". Based on the concept of market as a network interaction, concept of marketing system, as a medium for marketing policy, embracing innovations and marketing and linking both of them to economic growth and social development, and concept of multi-level product as a framework for categorising of innovations related to marketing, it is proposed to systematise marketing goals depending on the dynamic state of the marketing system, due to the ratio of supply and demand and the level of innovation, related to customer value. Marketing system concept is central to the entire construct since it permits to break with traditional marketing management mantra of maximising profit as a universal, imminent and unchanged marketing goal. Proposed systematisation shapes a continuum of goals, comprising paradigms from seller to buyer markets, including creation of intangible assets and reputation. Obtained results are of a bespoken importance for marketing planning and development of marketing key performance indicators (KPI). The article shows the bilateral triple connection between entrepreneurship, innovation and marketing in which a feedback provides for further development of innovations with information procurement and processing, and return of sales.

Key words: marketing, innovations, product, marketing system, marketing-management, marketing goals.

JEL classification: M30, M31, L11, L21. 